\title{
The Cebes and the uncompromising defense of the right to health and of democracy
}

EXACTLY 40 YEARS AGO, a group of young sanitarian doctors from the University of São Paulo proposed the creation of the Brazilian Center for Health Studies (Cebes), which would have as one of its objectives to promote, through a journal, "the analysis of the health sector as a component of the social-historical process" (CEBES, 1976, p. 3). The foundation of the Cebes and of the journal 'Saúde em Debate' occurred during the XXVIII Meeting of the Brazilian Society for the Advancement of Science (SBPC), held in July 1976 in Brasília. The journal quickly became one of the main vehicles of critical analysis of the determinants of health and of proposals of policies for the sector. Although emerged in the academia, through the journal and its clear position against the military regime, the Cebes gained affiliate members among health professionals and related areas, and created links with the ecclesial base communities, with the trade union movement, and with neighborhood associations and leftist groups. Some of the members gathered in nuclei, forming study groups, organizing seminars to discuss the entity documents, and became active divulgators of the journal. The Cebes played an important role in the emergence and strengthening of the so-called health movement as well as in the creation of the Unified Health System (SUS), having, since then, significant political influence in the sector.

The performance of Cebes during those 40 years was marked out for the defense of democracy as a value, as a timeless cause, whose rules must be respected by all and guaranteed by the institutions created to ensure the democratic game. The issue of democracy is intrinsic to the defense of the right to health as a right of citizenship, as well as of all other universal social rights.

Examples of this mode of operating from the Cebes can be recovered from the I Symposium on National Health Policy, sponsored by the Health Committee of the House of Representatives, held in 1979, which brought together the main leaderships and organizations concerned with the health situation in the country. In that event, the Cebes released the document entitled 'Democratization and health', which criticized the 'commodification/marketization of medicine' proposing the transformation of 'lucrative medical practices into a free social good available to the entire population'; the creation of a 'unified health system' and the assignment to the State of the 'full responsibility for the management of that system'. The document emphasized: "Grows [...] the anger of the population against the queues, the bureaucracy, the corruption, and the costs of the poor medical attention that they receive. [...] As that happens, the Brazilian medicine is experiencing a deep crisis. Criticisms to its quality are exacerbated.” (CEBES, 1981, p. 227). Reading this, one might say that little has changed. However, quite the opposite happened, much has changed. Of the approximately 120 million Brazilians in 1980, one third had no access to health services, and many of the services provided were inadequate (BRASIL, 1980, p. 20). Currently, almost the entire population has access to health services, especially since the adoption of the Family Health Strategy (ESF) as a model of care.

However, despite the great improvement that the ESF has brought regarding the access, it remains insufficient and inadequate. Compete for that various factors, such as the restriction 
of access to average and high complexity procedures, the lack of professionals with appropriate training, the poor infrastructure, management problems, and underfunding that accompanies the SUS since its inception. In that respect, one of the biggest problems has been the indefinite and reduced participation of the Federal Government. This suggests that the SUS, although enshrined in the Federal Constitution, was not taken by governments nor was it incorporated subjectively by important sectors of the Brazilian society (middle and upper class, unionized workers), i.e., they do not recognize the SUS as the universal public system of Brazil.

The Constitutional Amendment 29/2000 did not define a contribution floor to the Federal Government, linking the contribution to the GDP fluctuation, and the Constitutional Amendment 86/2015 infringed the Popular Initiative Bill (PLC No. 321/2013) with over 2.2 million signatures in favor of the minimum application of $10 \%$ of Current Gross Revenue in health. The replacement of the rule set by the CA 29/2000 to calculate the minimum federal spending based on percentages of Current Net Revenue, defined by the CA 86, imply a loss of approximately R $\$ 10$ billion for the year 2016. Article 38 of the Union Budget Guidelines Law, which defines that the current value of the minimum federal spending may not be less than the amount resulting from the application of the previous rule, was vetoed by the president. Meanwhile, the vote of the Constitutional Amendment Project 01/2015 based on the popular initiative Health +10 has been repeatedly delayed. On the other hand, transfers from government to the private sector through subsidized loans from the national treasury have grown significantly and exceed the house of $\mathrm{R} \$ 38$ billion estimated for 2016. This situation calls us to fight for the rejection of the veto to Article 38 and for the immediate approval of the CAP $01 / 2015$. However, this is not enough, we must continue to fight for the SUS we dreamt of in 1979.

Finally, in these times of political and institutional crisis that Brazil faces, the Cebes, through its major divulgation organ, reaffirms the value of democracy as a civilizational principle. It condemns the acts that endanger the fragile democracy conquered by the Brazilian society after 20 years of dictatorship and reaffirms: HEALTH IS DEMOCRACY!

Cornelis Johannes van Stralen

Presidente do Cebes

\section{References}

BRASIL. Ministério da Saúde. Conferência Nacional de Saúde, Brasília, DF, 24 a 28 de março, 7., Anais... Brasília, DF: Centro de Documentação do Ministério da Saúde, 1980.

CENTRO BRASILEIRO DE ESTUDOS DE SAÚDE (CEBES). Editorial. Rio de Janeiro, Saúde Debate, v. 1, n. 1, 1976. 